\title{
Analysing Linguistic Stylistic Devices in The Adventures of Tom Sawyer and So Long a Letter: A Comparative Appraisal
}

\author{
Servais Dieu-Donné Yédia Dadjo ${ }^{1}$ \\ ${ }^{1}$ FLASH Adjarra, Abomey-Calavi University, Benin \\ Correspondence: Servais Dieu-Donné Yédia Dadjo, Lecturer-Researcher, FLASH Adjarra, Abomey-Calavi \\ University, Benin. E-mail: dadservais@gmail.com
}

Received: October 31, 2021

Accepted: January 3, 2022 Online Published: January 10, 2022

doi:10.5539/ijel.v12n2p1

URL: https://doi.org/10.5539/ijel.v12n2p1

\begin{abstract}
This research work focuses on linguistic stylistic analysis of Mark Twain's The Adventures of Tom Sawyer and Mariama Bâ's So Long a Letter. It aims to identify the various translation procedures used in each novel in order to establish a comparison between the different translation procedures and style of each translator of modern and old English. A sampling method has been used to carry out this research work. Thus, one extract has been selected with its corresponding translation from the French and English versions of each novel. The results show that, in The Adventures of Tom Sawyer, the translator has used predominantly adaptation for his translation representing $32.32 \%$ in both selected extracts whereas in So Long a Letter, the translator has adopted predominantly literal translation representing a proportion of $28.48 \%$ in order to preserve the sustained register of the source text. However, both translators have also used other translation procedures in lower proportions depending on the context orientation. It has been noted that translation methods such as calque has been used only once whereas borrowing is nonexistent in the selected extracts from both literary works.
\end{abstract}

Keywords: adaptation, borrowing, calque, context, stylistic devices

\section{Introduction}

Language enables humans to express their ideas, emotions and desires basing on the social norms and cultural values of the societies they live in. Since language highly takes root in social contexts and traditions, it varies from community to community, from society to society and from country to country. So, in situations of different languages in contact, interactions are made possible through translations or interpretations depending on written or spoken languages in use. Translation is 'the transference of a message from one language to another' Nida (1964, p. 3). In this perspective, perfect knowledge of source and target texts is required for a successful translation or interpretation. In line with the preceding stated problem of translation or interpretation in the case of different languages in contact, this research work focuses on the analysis of linguistic stylistic devices in Mark Twain's The Adventures of Tom Sawyer and Mariama Bâ's So Long a Letter: a comparative appraisal. The study seeks to identify the various translation procedures used in each novel in order to establish a comparison between the different translation procedures and style of each translator of modern and old English.

It is important to note that The adventures of Tom Sawyer was first published in 1876. It is an old novel written by Mark Twain for entertainment. It describes American society where Tom symbolises American characters who fights against freedom in terms of religion, education and ethnics and rejects the social institution and does not want to be politically correct. In contrast, Mariama Bâ's So Long a Letter, published in 1979 is one long letter written by Ramatoulaye Fall to her best friend Aissatou after her husband Modou's death, during the mourning period. A letter written after thirty (30) years of marriage in which she describes in details her entire life. So it is important to study these literary works in order to establish the similarities and differences between them following a linguistic comparative stylistic perspective. This study is relevant as the scrutiny of the different translation procedures contributes to the deep understandings of the selected literary works.

\section{Literature Review and Theoretical Underpinning}

J. P. Vinay and J. Darbelnet (1958) in Comparative Stylistics of French and English: A Method of Translation, distinguish seven (07) categories of translation procedures.

\section{- Borrowing}


It is a translation technique that involves using the same word or expression in original text in the target text. Examples are: a coup d'Etat / un coup d'Etat; a rendez-vous / un rendez-vous.

\section{- Calque}

The process whereby the translator creates or uses a neologism in the target language by adopting the structure of the source language. Some instances are these pairs in English and French: skyscraper /gratte-ciel; cold war 1 guerre froide.

\section{- Literal Translation}

Also called metaphrase, literal translation refers to a word-for-word translation achieving a text in the target language. According to Vinay and Darbelnet (1958, p. 33), this translation procedure can only be applied with languages which are extremely close in cultural terms. It is only acceptable only if, the translated text retrains the same syntax, the same meaning, and the same style as the original text. Some instances are:

- Where are you / Où êtes- vous?

\section{- $\quad$ Avaler la pillule / To swallow the pill}

\section{- Transposition}

Transposition involves moving from one grammatical category to another without changing the meaning of the message. This translation technique introduces a change in grammatical structure.

- $\quad$ Noun to verb: For sale / $A$ vendre

- $\quad$ Adjective to noun: Medical students / Etudiant en médicine

- $\quad$ Adjective to verb: People are suspicious / Les gens se méfient

- Adjective to adverb: We do not have sufficient information on the case / Nous ne disposons pas suffisamment d'information sur ce cas.

- Adverb to noun: He spoke to the baby softly / Il parle au bébé avec douceur.

- Preposition to verb: She hurried into the church / Elle se dépêcha d'entrer dans l'église.

\section{- The interchange}

It is a common process of French expression: first the result, then the means. English by contrast follows the order of the images as illustrated through these instances: Blown away / emporté par le vent. He groped his way accross the room / Il traversa la pièce à tatons. He worked himself to death / Il s'est tué à la tâche.

\section{- Modulation}

Modulation refers to the process of changing the form of the text by introducing a semantic change or perspective. It is a variation of the form of the message, obtained by a change in the point of view. Therefore, we distinguish different type of modulation. Modulation by the negation of the opposite (litotes) as illustrated in the following examples. It is not difficult to show/ Il est facile de démontrer. Modulation through the use of abstract for concrete (metonymy) as indicated in these examples: Give a pint of your blood / Donnez un peu de votre sang. Modulation through the use of one part for another as illustrated in these examples: He cleared his throat: Il s'éclaircit la voix. Modulation through the use of the part for the whole (Synecdoche) as indicated in these examples: He shut the door in my face / Il me claqua la porte au nez. Modulation through the use of change of symbol (metaphor) as illustrated in the following instances: La moutarde lui monta au nez / He saw red. He lost his temper. Modulation through the use of active for passive and vice versa as shown in these instances: I was delighted by the book / Ce livre m'a enchanté

\section{- Equivalence or Reformulation}

This is a translation technique which uses a completely different expression to transmit the same reality. Through this technique, names of institutions, interjections, idioms, or proverbs can be translated as illustrated through these examples: Ouch! / Aïe!; Open to the public / Entrée libre. Mind your own business / Occupes toi de tes oignons; To beat around the bush / Tourner au tour du pot.

\section{- Adaptation}

It is the extreme limit of translation. It is used where the type of situation being referred to by the source language message is in the target language culture. Also called cultural substitution or cultural equivalent, it is a cultural element which replaces the original text with one that is better suited to the culture of the target language. This achieves a more familiar and comprehensive text as shown in these examples: Three men and a baby / 


\section{Trois hommes et un couffin; Baseball / Football.}

\section{- $\quad$ Prosody events}

This translation procedure includes dilution, amplification, economy, compensation, explicitation and implicitation. Dilution only applies to form. It occurs in translation, when in contact of two languages, the source language uses more words for the expression of the same idea than the target language as shown in these examples: Weeds / Les mauvaises herbes.

Amplification is the technique of remedying a syntactic deficiency, or to highlight the meaning of a word, in both cases by filling a lacuna in the lexicon or in the structure. The following examples indicate this: Passengers to Paris / Les passagers à destination de Paris. Paul wrote the letter / C'est Paul qui a écrit la lettre.

Economy refers to the opposite tendency to amplification. It is conveyed by a tightening up of the utterance obtained by quantitative or extensional reduction of a constituent signs. The following examples indicate this: The man I saw / L'homme que j'ai vu. Come and see me / Viens me voir.

Compensation occurs when an allusion or reference does not appear in one part of the text as in the source version but later in the target text. The following examples indicate this: They do not want me in any capacity / Ils ne veulent de moi nulle part.

Explicitation is a procedure through which some details which remain implicit in the source text but out of the context or situation are introduced in the target text. The following examples indicate this: Workers stay in jobs they hate for fear that a pre-existing medical condition will make them eligible for coverage elsewhere / Les employés gardent un emploi qu'ils détestent de peur que leur passé medical ne les empêche d'être couverts dans une autre entreprise.

Implicitation is the opposite of explicitation as exemplified here: Whatever he does next / Quoi qu'il fasse.

\section{Method}

In the attempt to carry out this research work, a sampling method has been used. Indeed, two chapters have been selected from each novel. This means that Chapter One (pp. 3-6) and Chapter Thirty-four (pp. 340-344) have been selected from The Adventures of Tom Sawyer whereas Chapter One (pp. 1-3) and Chapter Twenty-five (pp. 85-86) have been selected from So Long a Letter. Then, the frequency distribution of each translation procedure has been determined in both selected chapters from each novel and analysed. Relevant instances of each translation procedure have been provided for illustrations. It is important to precise that, for clarity sake, the illustrative instances in English are highlighted in bold whereas those in French are highlighted in italics. This has enabled the researcher to compare both literary works on the basis of the translation procedures and styles in the light of the linguistic comparative stylistic theory.

\section{Results and Discussion}

\subsection{Analysis of the Different Translation Procedures in Mark Twain's The Adventures of Tom Sawyer}

The different translation procedures used in Mark Twain's The Adventures of Tom Sawyer are summarised in Table 1 below in terms of frequency and percentage.

Table 1. Statistics of translation procedures in the selected Extract from The Adventures of Tom Sawyer

\begin{tabular}{lll}
\hline Translation procedures & Frequency & Percentage \\
\hline Literal translation & 22 & $9.48 \%$ \\
Borrowing & 00 & $00 \%$ \\
Calque & 01 & $0.43 \%$ \\
Transposition & 08 & $3.44 \%$ \\
Modulation & 25 & $10.77 \%$ \\
Equivalence & 15 & $6.46 \%$ \\
Adaptation & 75 & $32.32 \%$ \\
Amplification & 25 & $10.77 \%$ \\
Economy & 22 & $9.48 \%$ \\
Dilution & 06 & $2.58 \%$ \\
Concentration & 01 & $0.43 \%$ \\
Explicitation & 16 & $6.89 \%$ \\
Implicitation & 02 & $0.86 \%$ \\
Compensation & 14 & $6.03 \%$ \\
Total & 232 & $100 \%$ \\
\hline
\end{tabular}


The results of this section of investigation indicate that the translator has used predominantly adaptation while translating The Adventures of Tom Sawyer as mentioned in Table 1 above representing $32.32 \%$ of all the clauses used in the selected extract. The clauses analysis presented in Appendix 1 includes these adaptation clauses among others:

- (4) What's gone with that boy / Où a bien pu passer ce garçon

- (27) I never did see the beat of that boy! / Je n'ai jamais vu un garnement pareil!

- (43) What is that truck? / Que signifie tout ce barbouillage?

- (52) My! / Oh! mon Dieu!

- (61) Hang the boy / Maudit garçon!

- (103) I can't stand it / il n'y a rien à faire?

- (154) There / Tiens

- (209) He - well, there ain't ever any making of that boy out / On peut s'attendre à tout avec ce garcon

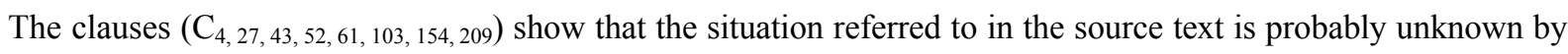
the translator, that is the reason why he has used completely different words or expressions to convey the same meaning.

As for literal translation clauses, they represent $9.48 \%$. The translator renders exactly what has been said in the source text. The following instances illustrate this:

- $\quad$ (Title) The Adventures of Tom Sawyer / Les Aventures de Tom Sawyer

- (6) The old lady / La vieille dame

- (41) Nothing / Rien

- (167) In which he thanked the widow / Dans lequel il remercia la veuve

- (192) Huck's rich / Huck est riche!

As for transposition clauses, they represent 3.44\%, the translator moves from one part of speech to another one without changing the meaning. The following pairs illustrate respectively the process involved in each of these transposition clauses below: (15) Noun / Adjective, (30) Noun / Verb, (39) Noun / Verb, (185) Adjective / Noun, (206) Adverb / Verb:

- (15) They were her state pair, the pride of her heart / Mais elle en était très fière

- (30) And looked out among the tomato vines / Et se mit à inspecter les rangs de tomates

- (39) I might 'a' thought of that closet / J'aurais bien dû penser à ce placard

- (185) And have him educated / Et pourvoir à son éducation

- (206) And inquiringly at Huck / Et regardèrent Huck.

As for modulation clauses they represent $10.77 \%$ in this Extract. Here, the translator shows his point of view by changing the form of the message. In the $\mathrm{C}_{21}$, he uses the modulation by the negation of the opposite to convey the same message. In clause $\left.{ }_{207}\right)$, he uses one part for another whereas in clauses $\left(C_{204,232}\right)$ he uses the part for the whole as indicated in these instances:

- (21) She did not finish / Elle en resta là

- (204) The company / Les gens

- (207) Who was tongue-tied / Qui ne soufflait mot

- $\quad$ (232) In property / En terres et en immeubles

Equivalence clauses represent $6.46 \%$ in Extract 1. Here, it is noticed that the translator has used idiomatic expression in clauses $\left(\mathrm{C}_{74,118,171}\right)$ and, interjection in $\left(\mathrm{C}_{98}\right)$ to transmit the same reality as illustrated below:

- (74) Spare the rod and spile the child / Qui aime bien, châtie bien

- $\quad$ (98) Shucks! / Chut!

- (118) Tend to your own business / De te mêler de ce qui te regarde

- (171) And so forth and so on / Etc

Amplification and economy represent respectively $10.77 \%$ and $9.48 \%$ in Extract 1 . It is noticed that while 
translating into French, the translator has added the underlined word, in order to fill a lacuna in the clauses $\left(\mathrm{C}_{3,53}\right.$, $107,122)$. While in the clauses $\left(\mathrm{C}_{75}, 148,201\right)$, he has reduced the constituent signs as illustrated in these instances:

- (3) I wonder/Je me demande

- (53) Look behind you, aunt! / Attention derrière toi, ma tante!

- (107) I'll take care of you / Descends et je m'occuperai de toi

- (122) This time / Cette fois-ci

- (45) As the Good Book says / Dit la Bible

- (148) And that's you / C'est toi

- (201) You just wait a minute / Attendez un peu

Dilution and concentration represent respectively $2.58 \%$ and $0.43 \%$ in Extract 1 . Here, the translator uses predominantly words in French translation to express the same idea. In the clauses, $\left(C_{9,31}, 166,211\right)$ he uses respectively 5 words versus 7 words; 01 word versus 2 words; 06 words versus 9 words; 02 words versus 5 words. Contrary to clause $\mathrm{C}_{205}$, in which he uses 08 words versus 02 words as illustrated in these instances:

- (9) Then she put them up / Puis elle les remonta sur son front

- (31) Weeds / Mauvaises herbes

- $\quad$ (166) Mr. Jones made his little speech / M. Jones se leva pour prononcer un petit discours

- (211) Tom entered / Tom rentra à ce moment

- (205) Looked at each other with a perplexed interest / Se regardèrent

Explicitation and implicitation represent respectively $6.89 \%$ and $0.86 \%$ in this Extract. Here, In the clause (16), the translator has been more explicit by telling whom 'She' refers to. Whereas, in the clauses $\left(\mathrm{C}_{92}, 223\right)$ the translator has been implicit as indicated in the example below:

- (16) She looked perplexed for a moment / La vieille dame demeura un instant fort perplexe

- (48) I'd skin you / Tu recevrais une belle correction

- (133) Everybody knows / Et que pas mal de gens savent déjà à quoi s'en tenir

- (92) But he hates work more than he hates anything else / Lui qui a une telle horreur du travail

- (223) There was scarcely an interruption from any one to break the charm of its flow / Que personne ne l'interrompit

Compensation represents $06.03 \%$ in this Extract. Here, it is noticed that the translator fills the lacunae in the source text by introducing some references which do not appear in the source text. In clause $\left(\mathrm{C}_{29}\right)$, he has pointed out where exactly the old lady stood in. the following examples show this:

- (29) And stood in it / La vieille dame alla se poster sur le seuil

- (113) Say / Mais, ajouta-t-il, qu'est-ce que je vois là

- (178) That he almost forgot the nearly intolerable discomfort / Que le brave garçon en oublia presque la gêne

- (219) All gazed, nobody spoke for a moment / Les spectateurs contemplèrent un instant ce monceau d'or.

\subsection{Analysis of the Different Translation Procedures in Mariama Bâ's So Long a Letter}

The table below displays the statistics of the different translation procedures used in Mariama Bâ's So Long a Letter. 
Table 2. Statistics of translation procedures in the selected Extract from So Long a Letter

\begin{tabular}{lll}
\hline Translation procedures & Frequency & Percentage \\
\hline Literal translation & 45 & $28.48 \%$ \\
Borrowing & 00 & $00 \%$ \\
Calque & 01 & $0.63 \%$ \\
Transposition & 03 & $1.89 \%$ \\
Modulation & 15 & $9.49 \%$ \\
Equivalence & 02 & $1.26 \%$ \\
Adaptation & 23 & $14.55 \%$ \\
Amplification & 16 & $10.12 \%$ \\
Economy & 06 & $3.79 \%$ \\
Dilution & 03 & $1.89 \%$ \\
Concentration & 00 & $00 \%$ \\
Explicitation & 37 & $23.41 \%$ \\
Implicitation & 04 & $2.53 \%$ \\
Compensation & 03 & $1.89 \%$ \\
Total & 158 & $100 \%$ \\
\hline
\end{tabular}

Source: Dadjo, 2021.

In contrast to the results observed in the previous section of the investigation, here, the translator has rendered literally the message conveyed in the source text. Indeed, literal translation represents $28.48 \%$ of all the clauses (158) used in Extract 2. After, follow explicitation (23.41\%) and adaptation (14.55\%) closely followed by amplification (10.12\%) and modulation (9.49\%). Economy, implicitation, transposition, compensation and equivalence are used at lower proportions comprising between $3.19 \%$ and $1.26 \%$ respectively. Only one (01) case of calque has been identified. In Extract 2 selected from Mariama Bâ's So Long a Letter, the translator has avoided using borrowing and concentration. The clauses analysis presented in Appendix 2 includes these clauses among others.

The following clauses demonstrate that the translator follows word for word translation to maintain the register in which Ramatoulaye Fall, the main character of the novel addresses Aissatou Bâ, her old friend:

- (37) Aujourd'hui, je suis veuve / Today I am a widow

- (60) Au bout, une chambre / At the end, a room

- (73) La secrétaire a eu la présence d'esprit de m'appeler/ The secretary had the presence of mind to call me.

- (94) Ses yeux rougis témoignent de quarante années d'amitié / His reddened eyes express forty years of friendship.

- $\quad$ (115) Votre fille est mon premier amour / Your daughter is my first love

As for transposition, the following instances stress the interchange which occurs while moving from French to English translation in the clause (59) and the translation of same identical part of speech to another one in the clauses $\left(\mathrm{C}_{74}, 114\right)$ as illustrated in the pairs (74) Noun / Verb, (114) Noun / Verb:

- (59) Qui n'en finit pas de s'étirer / Which seems to stretch out endlessly

- (74) Mawdo redit son arrivée tardive avec l'ambulance / Mawdo recounts how he arrived too late with the ambulance.

- (114) Je ne suis pas un chercheur d'aventures / I am not just looking for excitement.

Through metonymy the translator shows his point of view by changing the form of the message. In clauses $\left(\mathrm{C}_{7}, 58\right.$, 98), he uses abstract for concrete:

- (7) Ton existence dans ma vie n'est point hasard / Your presence in my life is by no means fortuitous

- (58) Un couloir qui s'étire / A long corridor

- $\quad$ (98) Son exactitude me plut / His punctuality pleased me.

As for equivalence, the clause (83) illustrates the use of idiomatic expression while in clause (1), 'Dear Aissatou' is directly the equivalence of "Aissatou" in English:

- (1) Aïssatou / Dear Aissatou, 
(83) Le bel âge a ses exigences de dignité / Middle age demands dignity

As for adaptation, the clauses $\left(\mathrm{C}_{13}, 85,136\right)$ show the use of different expressions to express the same reality. These are: "Fée-souris" replaced by "fairy godmothers" in $\mathrm{C}_{13}$.

- $\quad$ (Title) Une si longue lettre / So long a letter

- (13) En implorant Fée-Souris / In the same holes and begged our fairy godmothers

- (85) Je l'égrène avec ardeur en demeurant debout sur des jambes molles / I tell the beads ardently, remaining standing on legs of jelly

As far as amplification and economy are concerned, the translator has added word(s) in the clauses $\left(\mathrm{C}_{17},{ }_{34}, 48\right)$, whereas in clauses $\left(\mathrm{C}_{18}, 95,104\right)$, he has reduced them as clearly indicated these instances:

- $\quad$ (17) Je garde intacts mes souvenirs / I still keep intact my memories

- (34) Amie, amie, amie! / My friend, my friend, my friend

- (48) Vite! Plus vite! / Fast! Fast! Faster still!

- (113) Que je crois vous connaître / That I think I know you already

- (18) Sel de ma mémoire / The salt of remembrance

- $\quad$ (55) Des visages crispés / Distorted faces

- (104) Pas de séparation traîtresse / No treacherous gaps

As for dilution and concentration, the following examples emphasise the number of words used in the target text to express the same idea. In the clauses, $\left(\mathrm{C}_{9,15,39)}\right.$ the translator uses respectively 11 words versus 14 words; 02 words versus 04 words and 03 words versus 06 words:

- (9) Nos mères se disputaient la garde de nos oncles et tantes: Our mothers used to argue over who would look after our uncles and aunts

- (15) Plus belles / More splendid than before

- $\quad$ (39) Comment te raconter? / How am I to tell you?

Explicitation and implicitation clauses below indicate that the translator brings some details or keeps implicit in the target text. In the clause (28), he explains whose eyes are closed by using possessive adjective "my", while in clauses $\left(\mathrm{C}_{57,147}\right)$, "malgré eux" and "sa presentation" are respectively omitted:

- (28) Je ferme les yeux / I close my eyes

- (43) Mais, le plus souvent, il déséquilibre / But more often than not, it unsettles,

- (136) Comment manouvrer pour éviter le renvoi de ma fille! / What was to be done to prevent my daughter's expulsion from school?

- (57) De gens connus ou inconnus, témoins malgré eux de l'atroce tragédie/ Known and unknown, witnesses to this awful tragedy

- (147) Rien dans sa présentation ne changerait / There would be no change in him.

As for compensation, the translator gives some references to some realities which are not mentioned in the source text. In the clause (6) he specifies in whom confidence should be placed, which answer is 'in others'. Besides he has clearly mentioned the kind of realities he refers to in the clause (16):

- (6) Notre longue pratique m'a enseigné que la confidence noie la douleur/ Our long association has taught me that confiding in others allays pain

- (16) Si les rêves meurent en traversant les ans et les réalités / If over the years, and passing through the realities of life, dreams die

(44) Et heurte / Crosses you

\subsection{Discussion}

The results of the analysis carried out in the preceding section show that the translator uses different translation procedures to translate Mark Twain's The Adventures of Tom Sawyer. With 75 clauses representing $32.32 \%$ out of 232 clauses exanimated in Extract 1, adaptation is predominant. In 22 clauses representing 9.48\%, the translator transmits faithfully the source text by rendering word for word, what has been exactly mentioned as in the following clauses: (1) TOM! / Tom!, (6) The old lady / La vieille dame, (50) The switch hovered in the air 
/ La badine tournoya dans l'air, (108) Sid appeared / Sid apparu, (156) as the widow says / comme dit la veuve; and even for the title of the novel itself The Adventures of Tom Sawyer / Les Aventures de Tom Sawyer.

As far as modulation is concerned, it occurs in 25 clauses representing $10.77 \%$. Here, he has given his point of

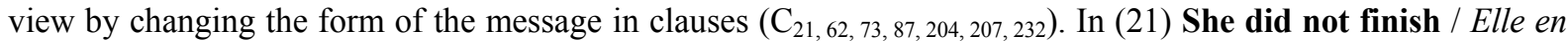
resta là, the translator shares his point of view by using an appropriate figure of speech (litote) to explain what Mark Twain directly means through 'She did not finish.'

Nevertheless, amplification and economy are opposite and are used in almost the same proportion respectively 25 and 26 clauses representing $10.77 \%$ and $9.48 \%$. Amplification adds words in French translation while

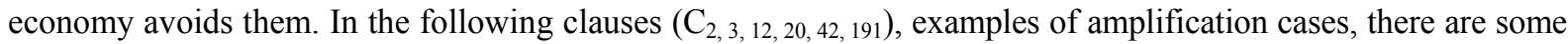
new words in French translation underlined as follows: (2) No answer / Pas de réponse, (3) I wonder / Je me demande, (12) as a boy / qu'un jeune garçon, (42) Nothing! Look at your hands, and look at your mouth / Rien? Regarde-moi tes mains, regarde-moi ta bouche, (191) Huck don't need it / Huck n'a pas besoin de tout

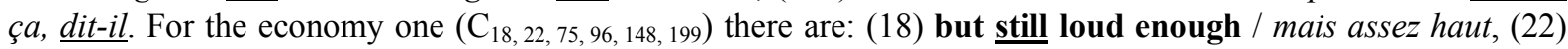
for by this time / car, (75) as the Good Book says / dit la Bible, (96) The window ain't high from the ground / La fenêtre n'est pas bien haute, (148) and that's you / C'est toi, (199) but he's got lots of it / mais il en a des tas. The translator adds or drops words in the translation to make the source text more intelligible for especially monolingual readers.

Some clauses have been directly translated in French whereas others' grammatical structure have been changed as noticed respectively in the clauses $\left(C_{38,48,49,74,78}\right)$ and $\left(C_{30,39,57,185,206}\right)$. For the clauses $\left(C_{7,9}, 31,168,169\right)$ representing dilution cases, the translator uses more words to convey the same meaning than the target language as in (31) and weeds / mauvaises herbes whereas in the clause (188) looked at each other with a perplexed interest / se regardèrent, he uses less words than the original text.

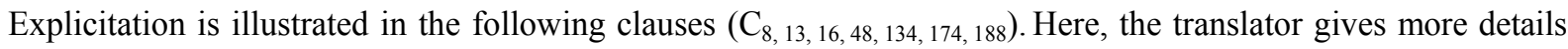
in the message conveyed according to the context or situation. In clauses $\left(\mathrm{C}_{92,223}\right)$, he remains implicit and deliberately avoids some details pointed out in the source text as in (92) but he hates work more than he hates anything else / lui qui a une telle horreur du travail, and in (223) There was scarcely an interruption from any one to break the charm of its flow / que personne ne l'interrompit.

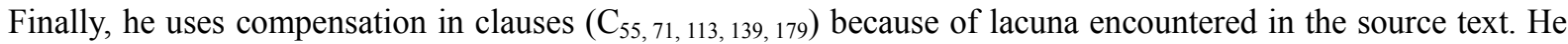
clearly emphasises it in $\left(\mathrm{C}_{139}\right)$ I reckon Mr. Jones was going to make a grand time over his surprise / Eh bien, le Gallois dira à tout le monde. Here, in the target text he first mentions who Mr. Jones is by replacing this name by 'le Gallois' in the target text and reveals what the translator would like to mean by the subordinate clause: 'to make a grand time over his surprise'. The calque occurs once through the clause (28) She went to the open door / La porte était ouverte. However, the translator avoids using borrowing in both selected Extracts.

As well, different translation procedures are also used for Mariama Bâ's So Long a Letter translation. With 45 clauses, representing $28.48 \%$, literal translation procedures are dominant. Through this method, in the clauses $\left(\mathrm{C}_{60}\right.$, $61,82,89,90,91,115,116,117)$ the translator renders word by word what has been mentioned in the source text. It is noticed that he often inverts the initial order of source clause as for instance in the clause $\left(\mathrm{C}_{118}\right)$ J'épouserai Aïssatou si vous êtes d'accord / If you agree, I will marry Aissatou. This is done to maintain the original register in which the source message is written. Nevertheless, in clause (59), he uses a special case of transposition: the interchange where in French the result comes first and then the means as represented in $\mathrm{C}_{59}$ : Qui n'en finit pas de s'étirer / which seems to stretch out endlessly. For the clause $\left(\mathrm{C}_{74}\right)$ Mawdo redit son arrivée tardive avec l'ambulance / Mawdo recounts how he arrived too late with the ambulance; and in $\mathrm{C}_{114}$ je ne suis pas un chercheur d'aventure / I'm not just looking for excitement; the translator changes the grammatical structure of 'arrivée' and 'chercheur' from noun to verb.

Through Modulation, the translator adopts metonymy to enable readers understand what the text is about. From abstract view he goes to a concrete result as in the clauses $\left(\mathrm{C}_{7 ; 58 ; 98}\right)$. Still through modulation, he uses synecdoche to translate $\mathrm{C}_{84}$ Je m'accroche à mon chapelet / I hold tightly on to my prayer beads. Here, the translator takes 'chapelet' for a part of 'my prayer beads' considered as the whole part and in $\mathrm{C}_{4} j$ 'ouvre ce cahier / I am beginning this diary, he precises that 'cahier' is a 'diary' indeed. The clauses $\left(\mathrm{C}_{1,83}\right)$ have been reformulated according to their direct English equivalence.

Adaptation represents $14.55 \%$. Here, he translates some clauses like $\left(\mathrm{C}_{13,85,136}\right)$ according to his understanding of the text; with his own words. For instance, in $\mathrm{C}_{13}$ En implorant Fée-Souris / and begged our fairy godmothers, he refers to 'Fée-Souris' as fairy godmothers whereas 'Souris' has nothing to do with 'Godmothers.' The same translation procedure is used for the title of the novel (Une si Longue Lettre / So Long a Letter). 
Sometimes, the translator adds or removes words in the target text. For clauses (17) je garde intacts mes souvenirs / I still keep intact my memories; (34) Amie, amie, amie! / My friend, my friend, $\underline{\mathbf{m y}}$ friend, (113) que je crois vous connaitre / that I think I know you already and (120) Nous continuerons nos études / We will continue with our studies. Here, he adds the word 'still'; the possessive adjective 'My' at the beginning of each 'friend,' the word 'already' and 'with' in the translated clauses. On the other hand, in the clause $\mathrm{C}_{104}$ 'Pas de separation traittresse / No treacherous gaps, he drops the article ' $d e$.' In other cases; he simply adds more words in the target text to express the same ideas as in clauses $\left(\mathrm{C}_{9,15,39}\right)$, which are dilution cases.

As far as explicitation and implicitation are concerned, the translator adopts those techniques to bring some details in the target text or to remain implicit. In clause (28) je ferme les yeux / I close my eyes. The translator uses the possessive adjective 'my' to precise whose eyes are closed whereas in clause (57) de gens connus ou inconnus, témoins malgré eux de l'atroce tragédie / Known and unknown, witnesses to this awful tragedy; and (147) Rien dans sa présentation ne changerait/ There would be no change in him. Here, words or expressions like 'malgré eux' and 'sa presentation' have been deleted.

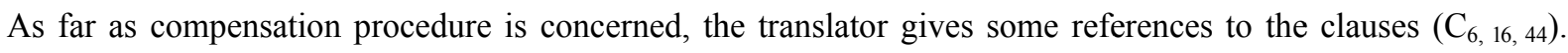
Therefore, calque appears just once in the clause (24) les feux de bois / the woodfires. Here, only one inverted compound noun is used to translate 'feux de bois.' It must be noted that the translator has avoided borrowing and concentration procedures.

The recapitulation of this research work is displayed in the simple bar charts below. The horizontal axis represents the translation procedures whereas the vertical one represents the proportions (percentages) of those translation procedures.

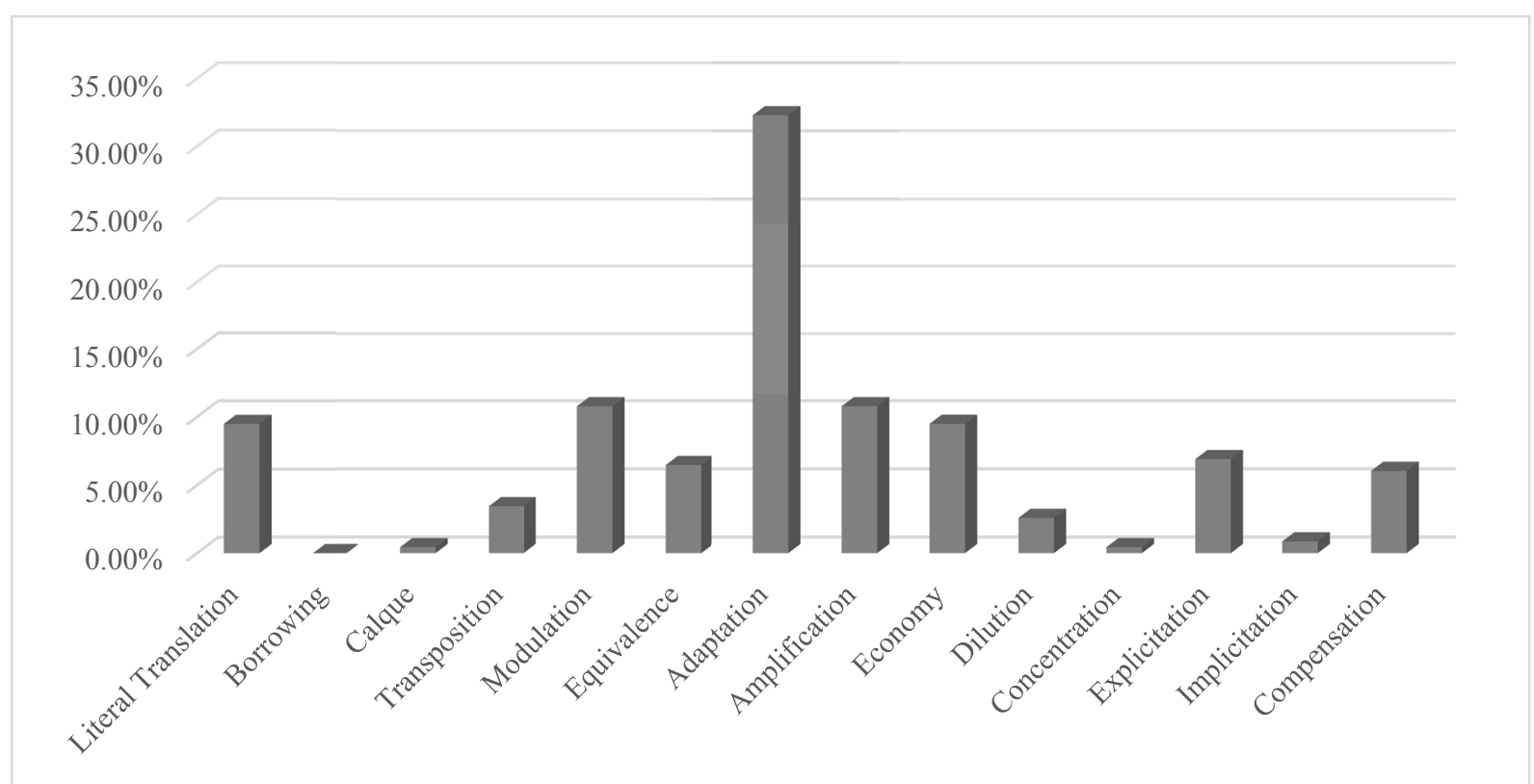

Figure 1. Statistics of the different translation procedures used in Mark Twain's The Adventures of Tom Sawyer 


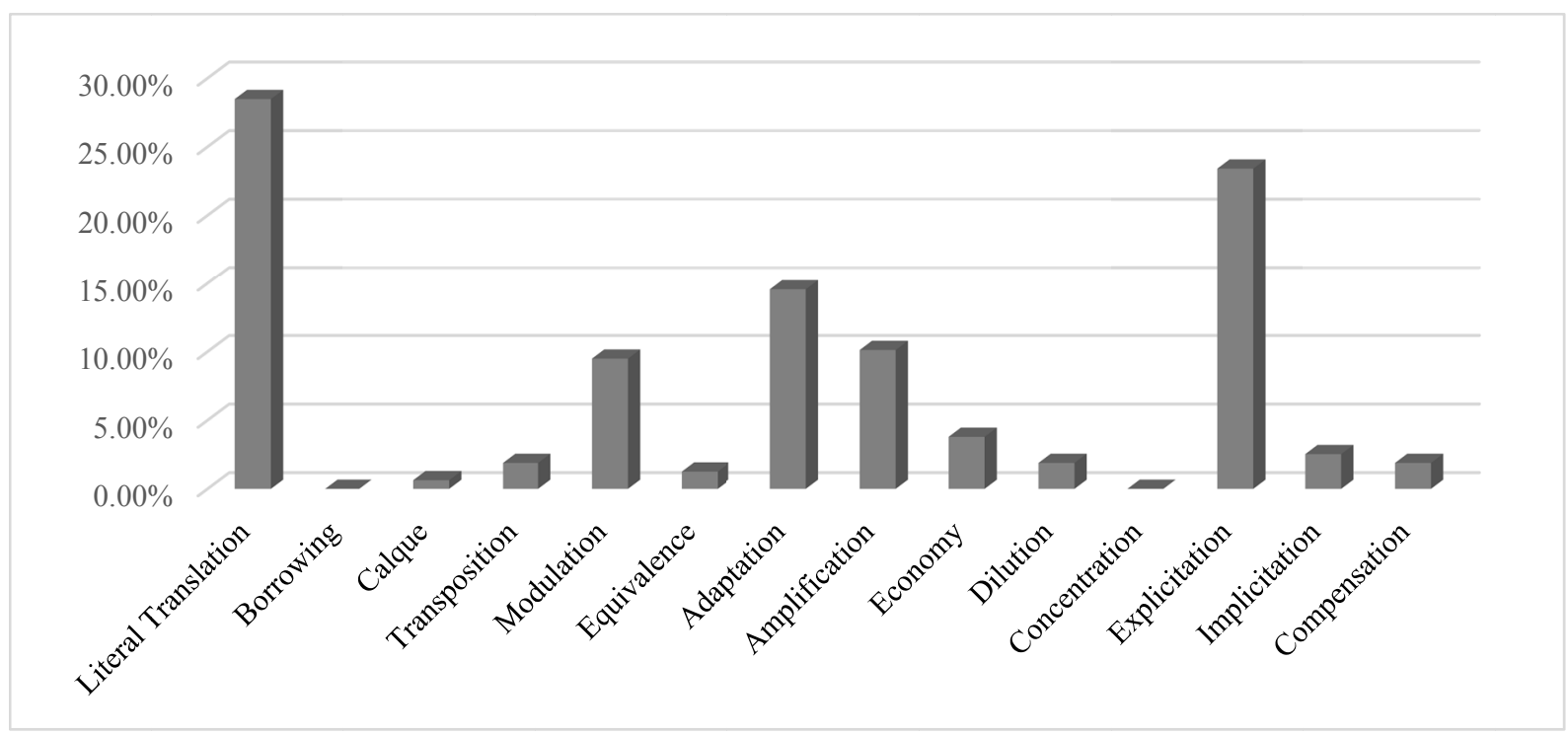

Figure 2. Statistics of the different translation procedures used in Mariama Bâ's So Long a Letter.

\section{Conclusion}

This research work has attempted to analyse linguistic stylistic devices in Mark Twain's The Adventures of Tom Sawyer and Mariama Bâ's So Long a Letter for the purpose of establishing a comparison between the different translation procedures and styles of each translator of modern and old English. The results show that different translation procedures have been used in Mark Twain's The Adventure of Tom Sawyer. Adaptation procedures are dominant with $32.32 \%$ whereas amplification and modulation represent each $10.77 \%$. Then, follow literal translation $9.48 \%$, economy $9.48 \%$, explicitation $6.89 \%$, equivalence $6.46 \%$, transposition $6.44 \%$, compensation $6.03 \%$, dilution $2.58 \%$ and implicitation $0.86 \%$. In the selected Extract, only one case of calque $\left(\mathrm{C}_{28}\right)$ representing $0.43 \%$ has been identified whereas borrowing is completely non-existent..

As far as Mariama Bâ's So Long a Letter is concerned, literal translation is used in a higher proportion representing $28.48 \%$ of all the clauses (158) in the selected Extract. Then follows explicitation (23.41\%), and adaptation (14.55\%) closely followed by amplification (10.12\%) and modulation $(9.49 \%)$. Economy, implicitation, transposition, compensation and equivalence are used at lower proportionsas they represent respectively $3.79 \%$, $2.53 \%, 1.89 \%, 1.89 \%, 1.26 \%$, Only one (01) case of calque has been identified. There is no borrowing and concentration. All this shows that while translating Mariama Bâ's So Long a Letter, the translator uses different translation procedures according to the context and situation or his point of views. Sometimes he introduces details to make the source text more understandable for the readers or to fill a given lacuna in the source text. For the simplest sentences, he adopts word-for-word procedure or simply uses idiomatic expression to transmit the same message for those sentences which have their equivalence in the second language. He also removes or adds word(s) to fill a lacuna or moves from one grammatical structure to another one. Therefore, one word, expression or sentence may be translated in several ways.

\section{Acknowledgements}

I hereby express my gratitude to Professors Léonard Koussouhon, Innocent Koutchadé and Celestin Amoussou for their unconditional supports.

\section{References}

Bâ, M. (1979). Une si longue lettre. Abidjan. Nouvelles éditions africaines.

Bâ, M. (1989). So Long a Letter (Translated from French by M. Bodé-Thomas, 1989). Waveland Press. Inc Heinenen ed.

Darbelnet, J. (1949). La Transposition. The French Review, 23(2).

Darbelnet, J. (1962). Traduction et Stylistique Comparée. Le Français dans le Monde, 1(6).

Darbelnet, J. (1970). Traduction littérale ou traduction libre. META, 15(2), 88-94. https://doi.org/10.7202/002478ar 
Darbelnet, J. (1983). Comparative stylistics as a linguistic discipline. Multilingua, 2(3), 127-133. https://doi.org/10.1515/mult.1983.2.3.127

Nida, E. (1964). Towards a Science of Translating: Introducing Corpora in Translation Studies. Leiden, London: Routledge. https://doi.org/10.1163/9789004495746

Twain, M. (1876). The adventures of Tom Sawyer written. Hartford ed.

Twain, M. (n.d.). The adventures of Tom Sawyer (Translated from English by P. F. Caillé \& Y. Dubois-Mauvais La Bibliothèque électronique du Québec, version 1.1, vol. 713). Collection à tous les vents.

Vinay, J. P., \& Darbelnet, J. (1958). Stylistique comparée du Français et de l'Anglais: Méthode de traduction. Paris: Didier

\section{Copyrights}

Copyright for this article is retained by the author, with first publication rights granted to the journal.

This is an open-access article distributed under the terms and conditions of the Creative Commons Attribution license (http://creativecommons.org/licenses/by/4.0/). 